\title{
PENERAPAN BUDAYA K3 PADA PETANI KARET DI DESA BENTAYAN \& KELUANG KECAMATAN TUNGKAL ILIR
}

\author{
Morlina Sitanggang ${ }^{1}$, Heri Setiawan ${ }^{2}$, Achmad Husaini ${ }^{3}$. \\ ${ }^{1}$ Universitas Katolik Musi Charitas, Email:dekan_fikes@ukmc.ac.id \\ ${ }^{2}$ Universitas Katolik Musi Charitas, Email: warek1@ukmc.ac.id \\ ${ }^{3}$ Universitas Katolik Musi Charitas
}

\begin{abstract}
Abstrak
Peningkatan kejadian kecelakaan kerja pada petani karet tradisional diDesa Bentayan dan desa Keluang Kecamatan Tungkal Ilir terjadi karena kurangnya pengetahuan dan rendahnya kesadaran tentang pentingnya menerapkan prinsip keselamatan dan kesehatan kerja di ladang karet. Berdasarkan hasil observasi dan wawancara dengan masyarakat Desa Bentayan dan Keluang yang mayoritas bekerja sebagai petani karet alam maka didapatkan data bahwa petani karet mengalami masalah kesehatan, utamanya gangguan saluran pernafasan, gangguan kulit dengan beberapa diantaranya mengalami gangguan pencernaan, hal ini terjadi karena petani kurang memahami tentang keselamatan dan kesehatan kerja dikarenakan rendahnya pengetahuan mereka serta belum adanya penyuluhan/pembinaan keselamatan dan kesehatan dalam bekerja. Metode Kegiatan dilaksanakan dalam bentuk penyuluhan kesehatan tentang keselamatan kerja, bahaya dan resiko penyakit akibat pekerjaan, pemeriksaan kesehatan resiko penyakit pada petani karet, SOP penggunaan APD di ladang karet dan pelatihan tata cara pemakaian APD bagi para petani/ pekerja diladang karet. Dari hasil workshop luaran yang diharapkan adalah peningkata pemahaman mitra berkaitan dengan Budaya Kesehatan dan Keselamatan Kerja (K3) dan penerapannya. Dari hasil pretest dan posttest diperoleh bahwa terjadi pengingkatan pemahaman mengenai budaya K3 pada nilai signifikasi sebesar 0.000 . Selain itu dari pemeriksaan kesehatan dapat disimpulkan bahwa secara umum mitra di kedua desa tidak memiliki masalah serius berkaitan dengan status kesehatan. Namun, ada beberapa penyakit yang perlu mendapat perhatian diantaranya: satu mitra mengalami masalah kulit, dan 12 peserta mengalami keluhan nyeri dada dan sesak nafas, dan tiga orang mengeluh jatung berdebar-debar dan mudah capek disertai sesak nafas.
\end{abstract}

Keywords: Petani Karet, Status Kesehatan, Pengetahuan, Penerapan Prinsip K3

Abstract

Increased incidence of accidents in traditional rubber farmers in Bentayan Village and Keluang Village Tungkal Ilir District occurred due to lack of knowledge and low awareness about the importance of applying the principles of occupational safety and health in rubber fields. Based on observations and interviews with Bentayan and Keluang villagers who mostly work as natural rubber farmers, it is found that rubber farmers have health problems, mainly respiratory problems, skin disorders with some of them having indigestion, this is because farmers do not understand about safety and health due to their low knowledge and lack of counseling / guidance of safety and health in work. Methods Activities are carried out in the form of health counseling on occupational safety, occupational hazards and risks, health risk checks on rubber farmers, SOPs on the use of $P P E$ in rubber fields and training on the use of PPE for farmers / workers in rubber fields. Based on the pretest and posttest result, it was found that there was an significant increase of understanding about OSH culture. Furthermore, from health examination it can be concluded that in general the partners in both villages do not have serious problems related to health status. However, there are some diseases that need attention include: one partner experiencing skin problems, and 12 participants experienced chest and shortness of breath pain, and three people complained of pounding and easily tired jaws accompanied by shortness of breath.

Keywords: Farmer, Rubber, Health, and K3 


\section{PENDAHULUAN}

Petani karet merupakan kelompok petani terbesar di Sumatera Selatan. Meski ada kecenderungan harga karet sejak tahun 2014 semakin menurun, Harga karet terus menunjukkan penurunan hingga memasuki tahun 2016. Angkanya masih tetap di kisaran $\mathrm{Rp}$ 5.000 per kg. Padahal, harga karet idealnya di kisaran Rp 12.000 per kg. Namun kendati kondisi harga karet terus menurun tetapi banyak wilayah kabupaten di Sumatera Selatan yang mengandalkan pertanian karet.

Menurut Dinas Pertanian dan Perkebunan Sumatera Selatan (2011), dari luas areal perkebunan seluas 2.391.249 Ha pada tahun 2010 maka sebagian besar atau hampir 50 persen berupa areal perkebunan karet atau seluas 1.195.111 hektar, selanjutnya berupa areal kebun kelapa sawit, kopi, kelapa dan tanaman perkebunan lainnya. Perkebunan karet (Hevea brasiliensis) di Provinsi Sumatera Selatan masih melibatkan banyak perkebunan rakyat.

Data Dinas Pertanian dan Perkebunan Sumatera Selatan tahun 2015 menyatakan bahwa kepemilikan perkebunan oleh rakyat atau berupa perkebunan rakyat mencapai $95 \%$ dari luas areal yang ada atau seluas sekitar 1135355 ha, memberikan banyak lapangan kerja atau sekitar 783.152 Kepala Keluarga, itu artinya sebagian besar pekerja dilahan karet adalah masyarakat/ petani rakyat.

Bekerja merupakan salah satu kegiatan utama bagi setiap orang atau masyarakat untuk mempertahankan hidupnya dan kehidupan. Dalam melakukan pekerjaan sebagai penyadap getah karet (Petani Karet), mempunyai risiko gangguan kesehatan atau penyakit yang ditimbulkan oleh pekerjaan tersebut, karena ketidaktahuan tenaga kerja mempunyai risiko yang lebih tinggi dalam kaitannya dengan gangguan kesehatan yang diderita akibat dari pekerjaan.

Kaitannya dengan faktor yang berpengaruh terhadap kondisi kesehatan, dalam melakukan penyadapan getah karet perlu dipertimbangkan berbagai potensi bahaya risiko yang bisa terjadi akibat cara kerja, penggunaan alat, dan bahan kimia pengental getah karet serta lingkungan yang basah di samping faktor manusianya, oleh karena itu perlu adanya upaya pencegahan dan pengendalian terhadap kemungkinan timbulnya gangguan kesehatan. Oleh karena itu faktor keselamatan dan kesehatan kerja merupakan masalah penting dalam setiap proses operasional petani dalam menyadap getah karet, baik penyadap kerja yang bekerja secara pribadi diperkebunan rakyat maupun diperkebunan milih badan usaha/perusahaan. Kondisi alam, cuaca, peralatan, dan bahan kimia yang digunakan dan suasana kerja yang kurang memperhatikan faktor keselamatan kerja tersebut masih belum menjadi kepedulian dan hal yang penting bagi petani karet.

Survey dan kunjungan di 2 Desa di Kecamatan Tungkal Ilir Kabupaten Banyuasin, yaitu Desa Bentayan dan Keluang, didapatkan data bahwa semua petani karet di desa tersebut dalam bekerja menyadap getah karet tidak memperhatikan faktor-faktor keselamatan dan kesehatan kerja. Berdasarkan hasil observasi dan wawancara dengan masyarakat Desa Bentayan dan Keluang yang mayoritas bekerja sebagai petani karet alam maka didapatkan data sebagai berikut: 1). Petani karet di Desa Bentayan dan 
Keluang mengalami masalah kesehatan, utamanya gangguan saluran pernafasan, gangguan kulit dengan beberapa diantaranya mengalami gangguan pencernaan, 2) Petani karet kurang memahami tentang keselamatan dan kesehatan kerja dikarenakan rendahnya pengetahuan mereka serta belum adanya penyuluhan/pembinaan keselamatan dan kesehatan dalam bekerja, 3). Petani karet dalam bekerja hanya memakai alas kaki berupa sandal, tidak memakai sarung tangan, menggunakan penutup kepala hanya berupa topi, dan memakai kaos, sebagian petani mengatakan bahwa pekerjaan tersebut telah dilakukan secara turun temurun dan tidak pernahmenggunakan alat pelindung diri, 4). Sebagian besar petani karet di kedua desa tersebut berpendidikan SD, bahkan terdapat beberapa orang yang tidak pernah mengenyam pendidikan formal sehingga tingkat pengetahuan terbilang rendah untuk memahami pentingnya keselamatan dan kesehatan dalam bekerja, 5). Adanya kasus keracunan cuka getah karet (larutan kimia pengental getah karet) yang pernah terjadi di wilayah desa Bentayan tersebut, akibat setelah "menating" (mengumpulkan) getah karet hanya cuci tangan biasa langsung makan.

Wawancara dengan seorang Perawat yang bekerja di Puskesmas Kecamatan Tungkal Ilir tentang keselamatan dan kesehatan kerjadiperoleh beberapa data yang mendukung pentingnya kebutuhan peningkatan pengetahuan dan kesadaran petani tentang keselamatan dan kesehatan kerja, yaitu: 1). Belum adanya program penyuluhan dan pelatihan K3 yang diselenggarakan oleh Puskesmas sebagai upaya promotif dan preventif dikarenakan keterbatasan petugas kesehatan dan keterbatasan waktu, 2). Belum adanya dukungan dari pemerintah setempat untuk meningkatkan kepedulian masyarakat terhadap pentingnya keselamatan dan kesehatan kerja, 3). Adanya prevalensi Infeksi Saluran Pernafasan Atas dan infeksi kulit pada pasien yang bekerja sebagai petani karet, dan 4). Kejadian kasus keracunan bahan kimia pengental getah karet pernah ditangani yang dialami oleh pasien yang merupakan petani karet di Desa Bentayan dan sering terjadi kasus gigitan ular pada petani saat bekerja di ladang karet. 


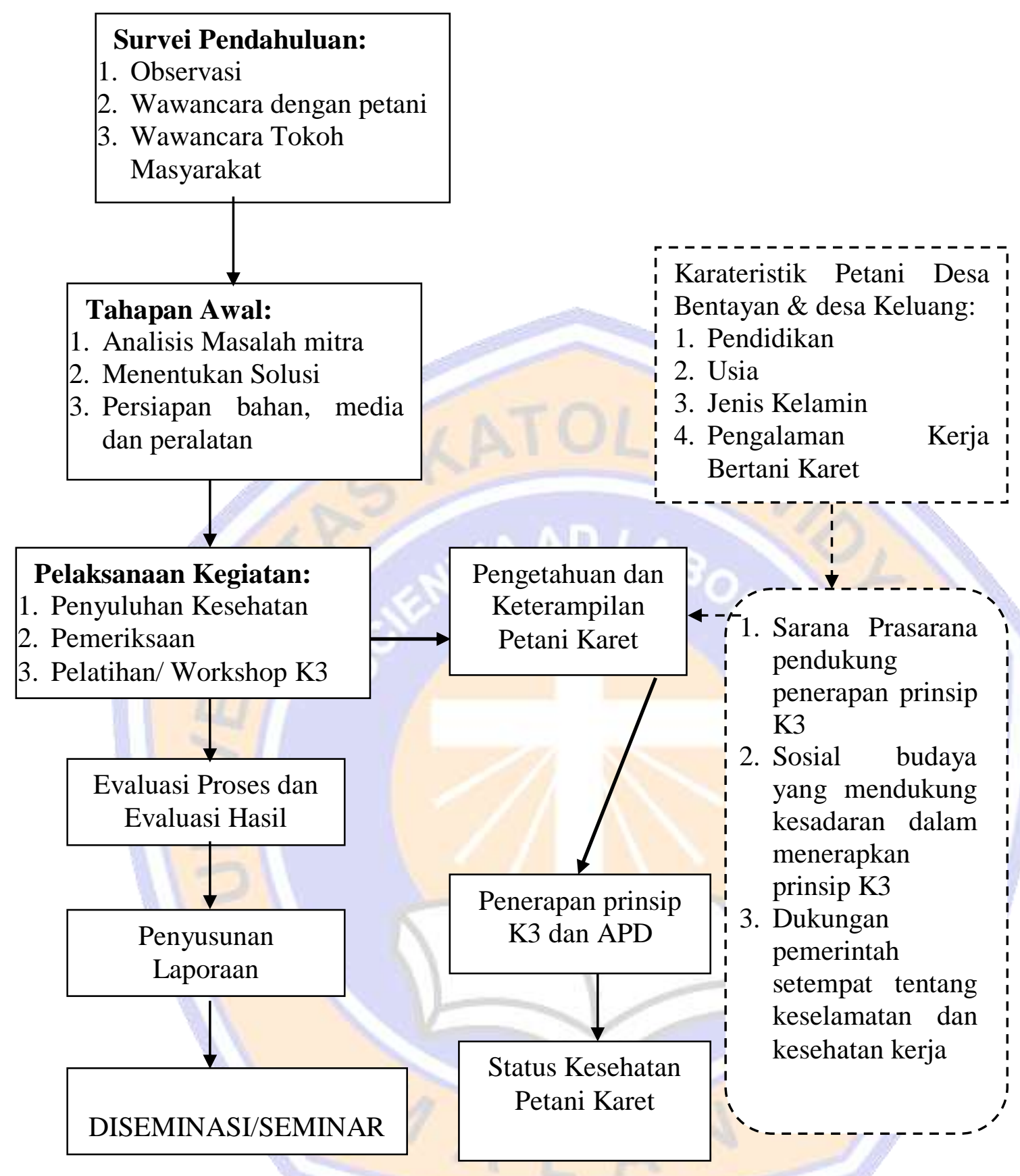

Gambar 1 Kerangka Alur Kegiatan peningkatan pengetahuan dan penerapaan keselamatan dan kesehatan kerja di Desa Bentayan dan Desa Keluang Kecamatan Tungkal Ilir Kabupaten Banyuasin

\section{METODE}

Metode yang digunakan dalam program kegiatan peningkatan pengetahuan dan penerapaan keselamatan dan kesehatan kerja di Desa Bentayan dan Desa Keluang Kecamatan Tungkal Ilir
Kabupaten Banyuasin ini (Gambar 1), adalah:

a) Penyuluhan kesehatan yang bertujuan untuk meningkatkan pengetahuan peserta kegiatan dan menfasilitasi petani untuk mengenali permasalahan kesehatan 
yang sedang terjadi dalam hal ini adalah petani karet yang ada di di Desa Bentayan dan Desa Keluang Kecamatan Tungkal Ilir Kabupaten Banyuasin, metode ini dipilih karena lebih efisien untuk jumlah masyarakat/ peserta yang banyak.

b) Workshop/pelatihan penggunakan APD dan penerapan keselamatan dan kesehatan kerja (K3) yang ditujukan kepada petani karet petani karet yang ada di di Desa Bentayan dan Desa Keluang Kecamatan Tungkal Ilir Kabupaten Banyuasin, metode ini dipilih karena metode pelatihan lebih mudah diserap, dipahami dan diterapkan oleh masyarakat tanpa harus mempertimbangkan derajat pendidikan para peserta kegiatan, sehingga peserta dari semua kalangan tingkat pendidikan dapat mengikuti kegiatan tersebut.

c) Pemeriksaan kesehatan yang ditujukan untuk petani karet petani karet yang ada di di Desa Bentayan dan Desa Keluang Kecamatan Tungkal Ilir Kabupaten Banyuasin bertujuan untuk mendeteksi dini adanya resiko bahaya dan resiko penyakit akibat pekerjaan bertani karet.

\section{HASIL DAN PEMBAHASAN}

Kegiatan Pengabdian kepada Masyarakat (PkM) dengan skema Ibtek Bagi Masyarakat (IBM) ini dilakukan oleh Tim Dosen Universitas Katolik Musi Charitas. Mitra dari kegiatan ini adalah petani-petani karet dari Desa Bentayang dan Desa Keluang, Kecamatan Tungkal Ilir, Kabupaten Banyuasin. Dari data yang dikumpulkan jumlah petani karet yang mengikuti kegiatan ini sebanyak 40 orang dari kedua desa.

Dari Tabel 1 dapat dijelaskan bahwa sebagian besar mitra yang mengikuti kegiatan pengabdian ini berusia antara 41 sampai 50 tahun, yaitu sebanyak 12 orang. Dari data yang diperoleh ada terdapat satu petani karet yang mengikuti kegiatan ini sudah berusia 71 tahun. Ada sekitar 10 petani karet yang memiliki rentang usia 21 sampai 30 tahun. Ini merupakan rentang usia yang produktif.

Tabel 1 Profil Mitra Berdasarkan Usia

\begin{tabular}{ccc}
\hline No & Usia (th) & Jumlah \\
& & 10 \\
1 & $21-30$ & 6 \\
2 & $31-40$ & 12 \\
3 & $41-50$ & 10 \\
4 & $51-60$ & 0 \\
5 & $61-70$ & 1 \\
6 & $71-80$ & \\
\hline
\end{tabular}

Tabel 2 menjelasakan mengenai profil mitra berdasarkan jenis kelamin. Dari data yang diperoleh sebagian besar mitra yang mengikuti kegiatan pengabdian kepada masyarakat ini memiliki jenis kelamin laki-laki, yaitu sebanyak 38 orang. Untuk mitra yang memiliki jenis kelamin perempuan hanya 2 orang. Dari gambaran ini dapat dianalisa bahwa sebagian besar perempuan atau ibu-ibu tidak menekuni profesi sebagai petani karet.

Tabel 2 Profil Mitra Berdasarkan Jenis Kelamin

\begin{tabular}{ccc}
\hline \multicolumn{3}{c}{ Kelamin } \\
\hline No & Jenis Kelamin & Jumlah \\
& & \\
\hline 1 & Laki-laki & 38 \\
2 & Perempuan & 2 \\
\hline & (Sumber: Data diolah) &
\end{tabular}

Tabel 3 menjelasakan mengenai profil mitra berdasarkan lamanya menjadi petani karet. Dari data dapat dijelaskan bahwa sebagian besar yaitu sebanyak 36 mitra memiliki waktu antara $0-10$ tahun menjadi petani karet. Hanya ada satu mitra yang sudah menjadi petani antara 11 sampai dengan 20 tahun. Dan dari data menunjukan ada 2 petani karet yang sudah lama yaitu antara 21 tahun sampai 30 tahun. Ada dua petani yang tidak mengisi form mengenai lamanya menjadi petani karet. 
Tabel 3 Profil Mitra Berdasarkan Lama Bekerja

\begin{tabular}{ccc} 
No & Lama Bekerja (th) & Jumlah \\
\hline 1 & $0-10$ & 36 \\
2 & $11-20$ & 1 \\
3 & $21-30$ & 2 \\
\hline
\end{tabular}

(Sumber: Data diolah)

Tabel 4 menjelasakan mengenai profil mitra berkaitan dengan tingkat pendidikan mitra. Dari Tabel 4 dapat dilihat bahwa sebagian besar mitra merupakan lulusan SMA, yaitu sebanyak 15 orang. Ada sebagian mitra yang baru menamatkan pendidikan Sekolah Dasar (SD), yaitu sebanyak 12 orang. Ada beberapa mitra yang juga merupakan tamatan Sekolah Menengah Pertama (SMP). Dari data ini dapat disimpulkan tinggkat pendikan mitra yang merupakan petani karet sangat beragam. Walau dari data menggambarkan lebih banyak petani karet yang sudah lulus SMA, tetapi perlu diingat banyak juga petani karet dilokasi mitra yang juga masih lulusan SD.

Tabel 4 Profil Mitra Berdasarkan Pendidikan

\begin{tabular}{ccc}
\hline No & Tingkat Pendidikan & Jumlah \\
\hline 1 & SD & 12 \\
2 & SMP & 11 \\
3 & SMA & 15 \\
\hline \multicolumn{2}{c}{ (Sumber: Data diolah) }
\end{tabular}

Beberapa kegiatan yang dilakukan dalam kegiatan pengabdian ini adalah penyuluhan mengenai kesehatan dan juga workshop tentang penerapan budaya Kesehatan dan Keselamatan Kerja (K3) bagi para petani karet. Salah satu tujuan dilakukan penyuluhan kesehatan dan workshop K3 adalah untuk meningkatkan pemahaman mitra mengenai pentingnya budaya hidup sehat dan juga K3 di lingkungan kerja.

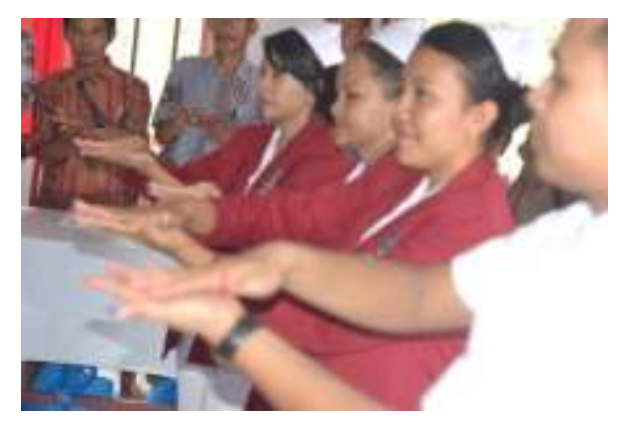

Gambar 2 Kegiatan Penyuluhan Kesehatan

Pada Gambar 2 ditunjukan kegiatan penyuluhan kesehatan yang dilakukan oleh Tim Pengabdian. Gambar 2 menunjukan penyuluhan kesehatan berkaitan dengan Perilaku Hidup Bersih dan Sehat (PHBS). Salah satu PHBS yang disosialisasikan kepada mitra adalah kegiatan mencuci tangan.

Kegiatan workshop mengenai budaya K3 juga merupakan salah satu hal yang penting dalam kegiatan ini. Selama ini budaya penerapan K3 pada mitra masih sangat minim sekali. Dengan workshop ini diharapkan kesadara mitra berkaitan dengan pentingannya penerapan budaya K3 meningkat. Pada Gambar 3 ditunjukan kegiatan workshop K3. Kegiatan workshop K3 di antaranya berupa pelatihan penggunaan alat pelindung diri (APD) bagi para petani/ pekerja diladang karet, berupa alat kelengkapan diri yang meliputi: sarung tangan (safety gloves), pakaian kerja yang tertutup dan berlengan panjang, penutup kepala (Topi), sepatu keselamatan (boot), masker, penggunaan lampu kepala.

Pelatihan memodifikasi alat pelindung diri sesuai dengan kearifan lokal, cara menggunakan peralatan pisau pahat, penggunaan cairan kimia pengental getah karet, cara mencuci tangan dengan benar, untuk memperkecil, menghindarkan diri dari kecelakaan dan keracunan dalam bekerja, dan perilaku hidup sehat dan bersih di rumah dan lingkungan kerja. 


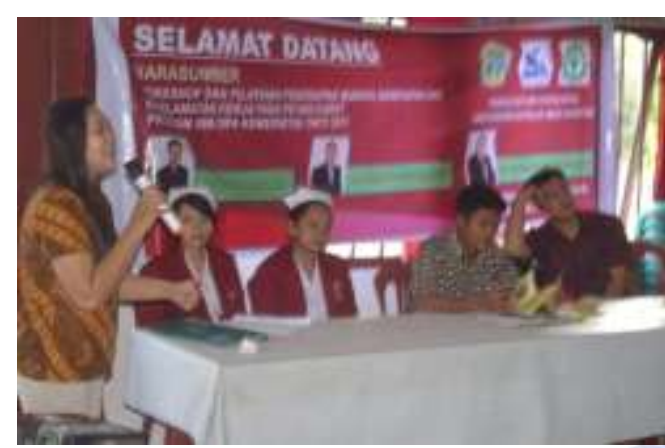

Gambar 3 Workshop K3

Target luaran dari kegiatan penyuluhan dan workshop K3 adalah peningkatan sikap, pengetahuan, dan perilaku berkaitan dengan K3. Untuk mengukur targer luaran tersebut, maka dalam kegiatan pengabdian ini dilakukan pengukuran pretest dan posttest persepsi mitra berkaitan dengan sikap, pengetahuan, dan perilakuk K3. Dari segi pendidikan sebagian besar mitra merupakan lulusan SD dan SMP, sehingga dalam pengujian pretest dan posttest diberi bimbingan oleh Tim Pengabdian.

Dimensi pertama yang yang dievaluasi adalah tentang pengetahuan mitra. Untuk mengukur pengetahuan mitra digunakan 15 indikator pertanyaan. Metode pengujian yang digunakan untuk dimensi pengetahuan adalah uji T-test. Hasil uji beda untuk pengetahuan dapat dilihat pada Tabel 5 di bawah ini

\begin{tabular}{|c|c|c|c|c|c|c|c|c|c|}
\hline & & \multicolumn{5}{|c|}{ Paired Differences } & \multirow[t]{3}{*}{$\mathrm{t}$} & \multirow{3}{*}{$f$} & \multirow{3}{*}{$\begin{array}{c}\text { S } \\
\text { ig. } \\
(2- \\
\text { tailed } \\
\text { ) }\end{array}$} \\
\hline & & \multirow[t]{2}{*}{$\begin{array}{l}\mathrm{Me} \\
\text { an }\end{array}$} & \multirow[t]{2}{*}{$\begin{array}{c}\text { Std. } \\
\text { Deviatio } \\
n\end{array}$} & \multirow[t]{2}{*}{$\begin{array}{l}\text { St } \\
\text { d. } \\
\text { Error } \\
\text { Mean }\end{array}$} & \multicolumn{2}{|c|}{$\begin{array}{c}\quad 95 \% \\
\text { Confidence } \\
\text { Interval of the } \\
\text { Difference } \\
\end{array}$} & & & \\
\hline & & & & & $\begin{array}{l}\text { Lo } \\
\text { wer }\end{array}$ & $\begin{array}{l}\text { Up } \\
\text { per }\end{array}$ & & & \\
\hline $\begin{array}{l}\quad P \\
\text { air } \\
1\end{array}$ & $\begin{array}{l}\text { PreT } \\
\text { otal - } \\
\text { PostTot } \\
\text { al }\end{array}$ & $\begin{array}{r}2.7894 \\
7\end{array}$ & $\begin{array}{r}3.67 \\
723\end{array}$ & $\begin{array}{r}.5 \\
9653\end{array}$ & $\begin{array}{r}3.9981 \\
5\end{array}$ & $\begin{array}{r}- \\
1.5808 \\
0\end{array}$ & $\begin{array}{r}4.67 \\
6\end{array}$ & 7 & $\begin{array}{l}.0 \\
00\end{array}$ \\
\hline
\end{tabular}

Gambar 4 Uji Beda Dimensi Pengetahuan

Dari Gambar 4 dapat dilihat disimpulkan pengetahuan mitra sebelum dan sesudah dilakukan pelatihan berbeda. Hal ini dilihat dari nilai Sig (2-tail) yaitu 0.00. Gambar 5.6 menunjukan nilai rata-rata jawaban benar dari hasil evaluasi pretest dan posttest. Dari Gambar 5.6 dapat dijelaskan bahwa rata-rata jawaban benar dari mitra setelah dilakukan pelatihan lebih besar yaitu sebesar 11.7368 dibandingkan dengan nilai rata-rata jawaban benar sebelum dilakukan pelatihan yaitu 8.9474. dengan data ini dapat disimpulkan mitra mengalami meningkatan pengetahuan berkaitan dengan K3. Dari hasil wawancara juga beberapa mitra tidak pengetahuan penggunaan prinsip K3 sebelumnya. Menurut mitra dengan pelatihan ini mitra memiliki pengetahuan yang baik berkaitan dengan penggunaan $\mathrm{K} 3$ di lingkungan kerja.

Untuk dimensi sikap dan perilakukan uji beda yang dilakukan dengan menggunakan metode Wilcoxon. Metode Wilcoxon digunakan untuk melakukan uji beda jika analisisnya menggunakan data nonmetrik (dalam hal ini data 
ordinal). Pada Gambar 5 ditunjukan hasil perhitungan uji beda untuk dimensi sikap. Hasil uji signifikansi metode Wilcoxon menunjukan bahwa nilai signifikansi pengujian adalah 0.000. Nilai ini menyipulkan bahwa secara nyata indikator sikap berbeda antara sikap sebelum dan sesudah dilakukannya pelatihan K3. Median nilai sikap setelah dilakukan pelatihan K3 lebih baik jika dibadingkan dengan sebelum dilakukan pelatihan.

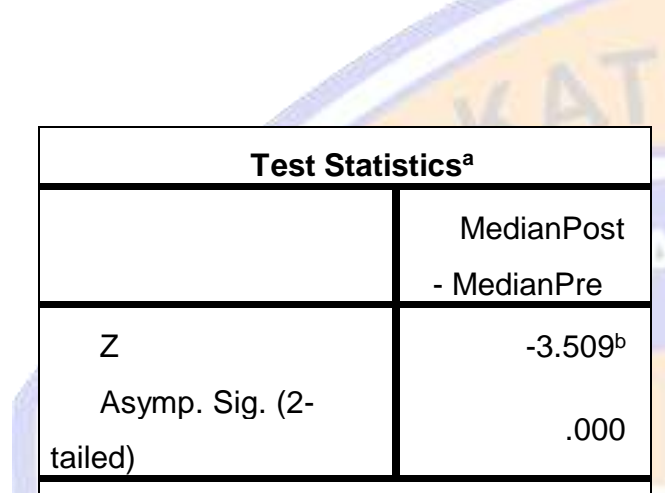

a. Wilcoxon Signed Ranks Test

b. Based on negative ranks.

Gambar 5 Nilai Signifikansi

dimensi Sikap

Pengujian selanjutnya adalah membandingkan antara tingkat persepsi perilaku mitra sebelum dan sesudah dilakukan pelatihan K3. Pada Gambar 6 ditunjukan hasil pengujian signifikansi untuk tingkat presepsi perilaku mitra sebelum dan sesudah dilakukan pelatihan K3. Dari Gambar 6 dapat dilihat nilai signifikansi pengujiannya adalah 0.000 . Dengan demikian dapat disimpulkan bahwa tingkat persepsi perilaku mitra sebelum dan seduah dilakukan pelatihan berbeda secara signifikan. Hal ini membuktikan ada penigkatan pemahaman mitra terhadap budaya K3 yang dicerminkan dalam hal perilaku. Setelah mengikuti kegiatan pengabdian yang dilakukan oleh Tim UKMC, persepsi mitra yang juga dicerminkan dalam kegiatan berbudaya K3 dalam bekerja menjadi lebih baik.

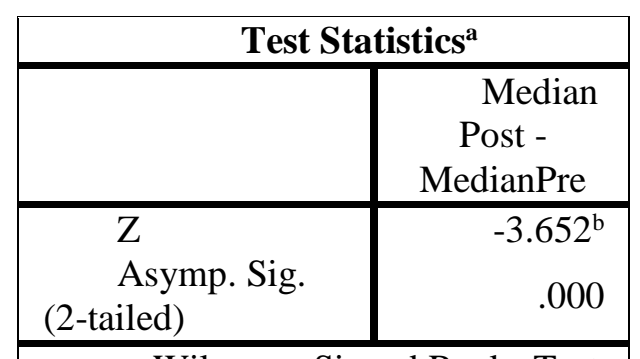

a. Wilcoxon Signed Ranks Test

b. Based on negative ranks.

Gambar 6 Pengujian Signifikansi Persepsi Perilaku Mitra

Dari ketika dimensi yang diujikan semuanya menunjukan tingkat signifikansi. Hal ini dapat diartikan bahwa mitra dalam kegiatan pengabdian ini memiliki peningkatan pemahaman mengenai Kesehatan dan Keselamatan Kerja (K3). Ini merupakan langkah awal yang baik. Namun, kedepan yang perlu untuk diperhatikan adalah kosistensi berkaitan dengan penerapan budaya K3 di lingkungan kerja.

Hal selanjutnya yang dilakukan dalam kegiatan pengabdian ini adalah pemeriksaaan kesehatan mitra. Mitra yang merupakan petani karet di Desan Keluang dan Bentayan tidak banyak memiliki akses kesehatan. Dengan budaya kerja selama ini yang tidak memperhatikan K3, maka dapat berdampak pada kesehatan mitra. Skrinning kesehatan ini diperlukan untuk mengetahui kondisi kesehatan mitra secara utuh. Ada beberapa pemeriksaan yang dilakukan dala kegiatan pengabdian ini yaitu, pemeriksaan fisik lengkap dan pemeriksaan darah.

Pemeriksaan yang dilakukan antara lain pemeriksaaN Indek Masa Tubuh (IMT), pemeriksaan tekanan darah, pemeriksaan fisik mata, pemeriksaan fisik telinga, pemeriksaan hidung, pemeriksaan fisik lidah, pemeriksaan pharynk, pemeriksaan tonsil, pemeriksaan fisik gigi, pemeriksaan tyroid, pemeriksaan fisik jantung, pemeriksaan paru-paru, pemeriksaan abdomen, reflek, 
pemeriksaan ekg, pemeriksaan $\mathrm{HB}$, pemeriksaan $\mathrm{HBsAg}$, pemeriksaan gula darah, pemeriksaan asam urat, pemeriksaan laju endap darah, dan pemeriksaan golongan darah. Semua kegiatan pemeriksaaan ini dilakukan dengan bantuan tenaga ahli kesehatan dan dokter. Secara keseluruhan hasil pemeriksaan tidak ditemukan masalah kesehatan yang serius.

Pada Gambar 7 ditunjukan hasil pemeriksaan kesehatan berkaitan dengan Laju Endap Darah (LED). Dari hasil pemeriksaaan terdapat 16 mitra yang memiliki laju endap darah yang tinggi.LED tinggi bisa mencerminkan adanya infeksi akut maupun kronik, respons yang tidak spesifik terhadap kerusakan jaringan dan merupakan petunjuk adanya penyakit. Peserta yang memiliki LED yang tinggi disarankan untuk memeriksaankan ke fasilitas kesehtaan untuk mengetahui penyebab LED tinggi.

\section{Hasil Pemeriksaan LED}

22

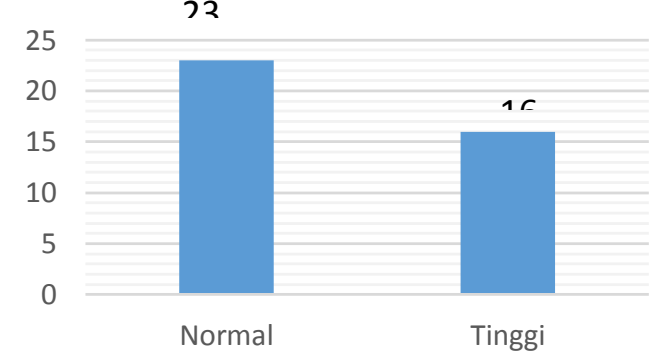

Gambar 7Hasil Laju Endap Darah (LED)

Secara umum hasil skrinning kesehatan menunjukan data yang tidak terlalu buruk berkaitan dengan status kesehatan. Dari hasil pemeriksaan skrinning ditemukan satu peserta yang mengalami gangguan kulit serius berupa daging tumbuh (benjolan) sebesar kepalan tangan. Peserta tersebut menggunakan karet untuk mengikat dengan tujuan agar tidak membesar. Pada pasien tersebut sudah diberikan penyuluhan untuk penanggulan dini. Penanggulang dini yang dimaksud adalah dengan membungkus benjolan tersebut dengan kain bersih dan melanjutan pengobatan ke Puskesmas. Selain hal tersebut diberikan informasi tentang pengurusan jaminan kesehatan BPJS. Terdapat 12 peserta yang mengalami keluihan nyeri dada dan sesak nafas dengan usia antara 38 Tahun sampai 47 Tahun. Tiga orang mengeluh jatung berdebar-debar dan mudah capek disertai sesak nafas dengan usia antara 30 tahun sampai 45 tahun. Selebihnya pemeriksaan fungsi jantung dan paru dalam batas normal. Sedangkan keluhan gangguan kulit berupa gatal-gatal ditemukan 38 orang (sebanyak 90\%). Untuk peserta yang mengalami sesak juga batuk, nyeri dada, dan mudah lelah disarankan untuk menghentikan aktivitasnya bila mengalami keluhan tersebut. Aktivitas dapat dilanjutkan kembali setelah peserta merasa lebih baik dan duanjurkan makan dan minum teratur, sehat dan bersih, istirahat yang cukup, menghidari stres, dan mengatur pernapasan jika mengalami masalah tersebut.

\section{SIMPULAN DAN SARAN}

Program pengabdian Ipteks bagi Masyarakat (IbM) tentang Penerapan Budaya Keselamatan dan Kesehatan Kerja Pada Petani Karet di Desa Bentayan dan Desa Keluang Kecamatan Tungkal Ilir dapat dijalankan dengan baik. Ketua dan anggota timbekerja sama dengan baik. Selain itu partisipasi mitra yaitu petani karet di Desa Bentayan dan Desa Keluang juga sangat atusias dan bisa bekerja sama dengan baik. Untuk laporan akhir kegiatan pengabdian Ipteks bagi Masyarakat (IbM) ini ada beberapa kesimpulan yang bisa dihasilkan, antara lain:

a. Secara umum luaran yang ditargetkan tercapai. Dari lima luaran yang ditargetkan semuanya sudah terpenuhi..

b. Luaran pertama adalah peningkatan pemaham mengenai budaya K3. Dari hasil pretest dan posttest dapat disimpulkan pemahaman mitra mengenai budaya K3 mengalami peningkatan. Hal ini disimpulkan dari 
hasil pengujian statistik yang menunjukan nilai signifikasi perbedaan antara pretest dan posttest adalah 0.000

c. Dari hasil skrinning status kesehatan sebanyak $100 \%$ mitra mengikuti pemeriksaan fisik lengkap dan rekam jantung. Dari hasil pemeriksaan tersebut ada 1 peserta yang mengalami masalah kulit, 12 peserta yang mengalami peserta yang mengalami keluihan nyeri dada dan sesak nafas, dan tiga orang mengeluh jatung berdebar-debar dan mudah capek disertai sesak nafas.

Kegiatan pengabdian kepada masyarakat sangat besar manfaatnya bagi petani Karet di desa Bentayang dan Keluang. Selama ini masyarakat kurang memahami bagaimana pentingnya menerapkan K3 di lingkungan kerja kebun karet. Dari kegiatan ini ada beberapa hal yang masih perlu mendapat perhatian. Beberapa hal yang perlu menjadi perhatian guna mendukung keberasilan kegiatan ini adalah:

a. Petani karet diharapkan menggunakan secara benar dan rutin APD yang diberikan oleh tim pengabdian.

b. Meningkatkan pemanfaatan fasilitas kesehatan masyarakat seperti Puskesmas untuk memeriksa status kesehatan masyarakat di desa Bentayang dan keluang.

c. Bagi pihak yang berwenang memfasilitasi pengurusan jaminan kesehatan masyarakat BPJS untuk membantuk petani karet dalam melakukan pengobatan terhadap penyakit yang diderita.

\section{UCAPAN TERIMA KASIH}

Ucapan terima kasih disampaikan kepada Direktur Jenderal Kementerian Riset dan Teknologi Pendidikan Tinggi karena pelaksanaan program pengabdian kepada masyarakat ini dapat berjalan dengan baik berkat dukungan dana yang penuh melalui skema pendanaan Iptek Bagi Masyarakat (IbM).

\section{REFERENSI}

Brunner \& Suddarth.2002.Buku Ajar: Keperawatan Medikal Bedah Vol 2, EGC, Jakarta

Laraia, Stuart. (2005). Principles and Practice of Psychiatric Nursing 8 Edition. Philadelpia: Elsevier Mosby. Diposting dari http//.ui.ac.id. Diakses tanggal 12 Juni 2013

Lewis. dkk, (2011) Medical Surgical Nursing, Assessment and Management of Clinical Problem, Elsevier. Mosby

Notoatmadjo, Soekijo.1996.Ilmu Kesehatan Masyarakat. Jakarta : Penerbit Rineka Cipta

Notoatmodja, Soekdjo. 2003. Ilmu Kesehatan Masyarakat PrinsipPrinsip Dasar. Jakarta: Rineka Cipta

Price dan Wilson, (2012). Patofisiologi Konsep Klinis Proses-proses Penyakit. Edisi ke 6. Jakarta. EGC

Santoso, G. 2004.Manajemen Keselamatan dan Kesehatan Kerja. Prestasi Pustaka, Jakarta.

Suardi, R. 2005. Sistem Manajemen Keselamatan dan Kesehatan Kerja. Penerbit PPM, Jakarta.

Sugeng, A.M., dkk. 2005. Bunga Rampai Hiperkes \& KK Edisi II. Badan Penerbit Universitas Diponegoro, Semarang

Suyono.2012. Ilmu Kesehatan Masyarakat dalam Konteks Kesehatan Lingkungan. Jakarta: EGC 